Article

\title{
Assessment of Air Pollution with Polychlorinated Dibenzodioxins (PCDDs) and Polychlorinated Dibenzofuranes (PCDFs) in Lithuania
}

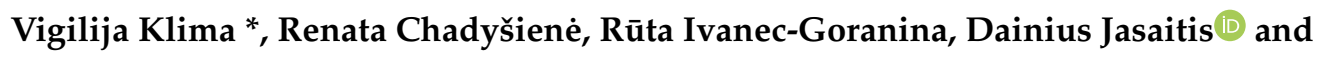 \\ Vaida Vasiliauskienè \\ Faculty of Fundamental Sciences, Vilnius Gediminas Technical University, Saulètekio Ave. 11, \\ 10223 Vilnius, Lithuania; Renatika@gmail.com (R.C.); Ruta.Ivanec-Goranina@vgtu.lt (R.I.-G.); \\ Dainius.Jasaitis@vgtu.lt (D.J.); Vaida.Vasiliauskiene@vgtu.lt (V.V.) \\ * Correspondence: Vigilija.Klima@vgtu.lt
}

Received: 6 June 2020; Accepted: 15 July 2020; Published: 17 July 2020

\begin{abstract}
Polychlorinated dibenzodioxins and polychlorinated dibenzofurans (PCDD/F) are highly bioavailable in humans, either through direct inhalation or indirectly by trophic transfer from contaminated food or water. The main sources of pollution with PCDD/F include industrial and non-industrial combustion sources, like domestic contaminated wood burning, house fires, burning of leaves from trees, etc. When looking for alternative energy sources and reduced energy costs, solid waste incineration plants are intended to be built in the vicinity of urbanized areas, and thus, the need emerges for examination and prediction of to what extent the solid waste incineration plants might affect the surrounding ecosystem, air pollution, and human health. Polychlorinated dibenzo-p-dioxins (PCDDs) and polychlorinated dibenzofurans (PCDFs) (or simply $\mathrm{PCDD} / \mathrm{F}$ congeners) belong to the group of semi-volatile organic compounds with environmental stability and long-range transfer in the ambient air. Dioxin isomers are highly toxic and may have carcinogenic and mutagenic effects in humans. PCDD/F is detected in air, water, sediment, plants and animals. PCDD/F is generally distributed in the particulate phase in ambient air. For solid waste incineration plant emissions, the distribution of $\mathrm{PCDD} / \mathrm{F}$ particles into particles with a diameter of $<10 \mu \mathrm{m}$ is more than $81 \%$ of the total particulate matter, and more than $54 \%$ of the PCDD/F is distributed into particles with a diameter of $<2.5 \mu \mathrm{m}$. The aim of this study is to investigate the sources of PCDD/F, emissions and potential hazards, i.e., a toxic equivalent in Lithuania. The measurements were performed in two largest cities of Lithuania Vilnius and Kaunas, where the level of PCDD/F discovered was from 0.015 to $0.52 \mathrm{pg} / \mathrm{m}^{3}$ and from 0.02 to $0.05 \mathrm{pg} / \mathrm{m}^{3}$, respectively. The sites for the monitoring were selected based on their proximity to the locations of the planned cogeneration power plants in these cities.
\end{abstract}

Keywords: polychlorinated dibenzo-p-dioxins (PCDDs); polychlorinated dibenzofurans (PCDFs); air pollution; house fires

\section{Introduction}

Polychlorinated dibenzo-p-dioxins (PCDDs) and polychlorinated dibenzofurans (PCDFs) (or simply $\mathrm{PCDD} / \mathrm{F}$ congeners) belong to the group of semi-volatile organic compounds. These compounds are comparatively stable in air (the lifetime ranges between 2 and 20 years $[1,2]$, and can be transported for long distances and/or stored in the ecosystem through a food chain. As a result of a high toxicity, PCDD/F can cause heart problems, disrupt the immune, endocrine system, lead to different forms of cancer, skin rashes [3]. The World Health Organization (WHO) recommends 
a regular assessment of the impact of air pollutants on the human's ecosystem and of the health risk associated with human exposure to pollution, as well as an assessment of the trends in exposure duration and the effectiveness of specific management measures (WHO).

The main source of PCDD/F is anthropogenic processes related to fuel combustion. PCDD/F emissions from non-industrial sources are difficult to quantify since they can be originated from several sources (e.g., some accidental fireplaces, fireworks, diesel engines, burning of pentachlorophenolcontaminated wood products and illegal household waste incineration, etc. [4]), where the process of combustion and contamination is usually out of control. Therefore, estimates of emissions from this kind of sources are usually inaccurate. The obvious difference between industrial and non-industrial sources: industrial source emissions are easy to measure, and can therefore be controlled by regulatory emission limits, unlike non-industrial sources [5]. However, in both cases, emission levels are mostly influenced by the degree of social awareness of the population [6,7].

Formation of $\mathrm{PCDD} / \mathrm{F}$ is determined by a high temperature chemical reaction between organic compounds and chlorine. The main sources of PCDD/F contamination (see Table 1) are waste incineration, metallurgical industry [8], coal and wood boiler houses, as well as fires and fireworks [9].

Table 1. Main sources of polychlorinated dibenzofurans (PCDD/F) contamination and their emission factors.

\begin{tabular}{lcc}
\hline \multicolumn{1}{c}{ Main Sources of PCDD/F } & PCDD/F, $\mu \mathrm{g}$ I-TEQ/t & References \\
\hline Municipal solid waste incineration & $50 \mathrm{ng}$ I-TEQ/kg & {$[8]$} \\
Domestic clean wood burning & $0.043-11 \mu \mathrm{g} \mathrm{I-TEQ/t}$ & {$[10]$} \\
Domestic contaminated wood burning & $11-400 \mu \mathrm{g} \mathrm{I-TEQ/t}$ & {$[10]$} \\
Bonfire & $10 \mu \mathrm{g} \mathrm{I}-\mathrm{TEQ} / \mathrm{t}$ & {$[10]$} \\
Fireworks & $142 \mathrm{ng} \mathrm{I-TEQ/kg}$ & {$[11]$} \\
Tobacco combustion & $0.05-0.2 \mu \mathrm{g} \mathrm{I-TEQ/Mg}$ & {$[12]$} \\
Forest fires & $2.0 \mu \mathrm{g} \mathrm{I-TEQ/t}$ & {$[13]$} \\
Leaves from trees burning & $4.6 \mu \mathrm{g} \mathrm{I-TEQ/t}$ & {$[14]$} \\
Untreated wood burning & $0.77-29 \mu \mathrm{g} \mathrm{I-TEQ/t}$ & {$[15]$} \\
House fires & $22 \mu \mathrm{g} \mathrm{I-TEQ/t}$ & {$[16]$} \\
\hline
\end{tabular}

$\mathrm{PCDD} / \mathrm{F}$ traces are detected in air, water, sediment, plants and organisms of animals. Atmospheric transfer is the main process leading PCDD/F deposition in terrestrial and aquatic ecosystems [17]. Waste incineration process generates large amounts of PCDD/F levels of chlorine and copper in the waste [18]. In recent years, solid waste incineration has become one of the strategic waste management alternatives $[19,20]$. Although PCDD/F is usually produced during many combustion processes as a by-product, it was recently highlighted as one of the major emissions [21]. Iñiguez and colleagues found that, below 400-500 K, the atmosphere does not affect the thermal degradation. However, at temperatures between 500 and $800 \mathrm{~K}$, the presence of oxygen accelerates the decomposition, so the mass loss rate is higher in combustion than in pyrolysis [22]. Almost all organic compounds, including dioxins, are prone to decomposition at $850^{\circ} \mathrm{C}$ [23]. PCDD/F contamination usually binds to organic and/or inorganic particles with a diameter of $<10 \mu \mathrm{m}$. For lower diameter of organic/inorganic particles $(<2.5 \mu \mathrm{m})$, the ratio of number of PCDD/F molecules bound to particles decreases by nearly 35 percent [24].

The main mechanism of PCDD/F formation is called de novo synthesis reaction, which results in oxidative degradation and transformation of the macromolecular carbon structure into aromatic compounds [25]. The vapour phase PCDD/F emission can be controlled, e.g., by using activated carbon filters and/or by a selective catalytic reduction. The removal or transformation of the gaseous PCDD/F in the troposphere occurs due to dry or wet precipitation, photolysis and reaction with $\mathrm{OH}, \mathrm{HO}_{2}$, $\mathrm{NO}_{3}$ radicals and $\mathrm{O}_{3}$ molecules. Concerning the particulate phase PCDD/F contamination, this phase is mainly controlled by means of electrostatic precipitators and bag filters [26,27]. The industrial emissions of PCDD/F are currently decreasing, however, due to the long half-life (5-15 years) of 
$\mathrm{PCDD} / \mathrm{F}$, the problems related to the presence of PCDD/F in the food chain will continue for a decade or more, even after the new releases are significantly reduced [1].

Compared to other waste treatment methods (landfills, bio-recycling), incineration has the following advantages: volume reduction by $85-90$ percent, weight reduction by $65-80$ percent [28], energy production and pathogen removal. A number of studies [29-31] reveal that modern waste incineration plants have little environmental impact, compared to other waste disposal alternatives or other industrial activities. The EU Member States and the EC have developed strategies to reduce dioxin emissions. In developed countries, the trend of decreasing PCDD/F concentrations has been observed, especially after the adoption of national and international regulations regulating emissions [8].

In Lithuania, according to the data of 2016, about 30 percent of waste is landfilled, 5 percent is stored, 48 percent is recycled, and 17 percent is burned (EUROSTAT). The amount of PCDD/F in ambient air is higher in winter season [32-34]. Thus, a monitoring of the PCDD/F emissions in atmosphere is an important factor while trying to assess concentration of pollutants depending on location, meteorological parameters [31], transport mechanisms, sedimentation and dispersion [35] or even seasonal changes.

Studies of PCDD/F concentrations in the air have not been conducted in all European countries. National PCDD/F research programs and controls across each country are needed to assess PCDD/F concentrations in the environment that may affect public health and their potential sources. PCDD/F concentration studies should include ambient air, soil and water in urban, industrial and rural areas.

In this study, we focus on the main sources and variations of PCDD/F in the ambient air in Vilnius and Kaunas (two largest cities in Lithuania), by considering depletion of city transport vehicle exhaustions, emissions from non-industrial (e.g., illegal household waste incineration) and industrial sources (i.e., activity of the planned cogeneration power plant), and with respect to the influence of prevailing wind direction, temperature, humidity and barometric pressure, as well as on its potential impact on humans and biota.

\section{Research Methodology}

\subsection{Main Characteristics of the Tested Urbanized Territory and the Laboratory for Experimental Measurements}

The research of PCDD/F concentration in ambient air was carried out in Vilnius and Kaunas, cities with a population of 1432 and 1826 people per square kilometre, respectively. The National Sustainable Development Strategy [36] provided for the improvement of the systems for assessment and management of environment quality, to ensure the quality of air necessary for public health and ecosystems across the country. According to air quality monitoring data, the environment in Lithuania is better than that in many other countries across the world. Although Lithuania is recognized as the global leader in terms of improvement of air quality and increase of forested area [36], up to now, however, there have been no attempts of direct measuring and/or monitoring of PCDD/F absolute concentrations in ambient air. Lithuania intends to build 2 new cogeneration power plants in Vilnius and Kaunas in 2020-2021. PCDD/F measurements have been performed before their operation to determine the concentration of air pollutants in ambient air.

The sampling location for monitoring of PCDD/F concentration in air was selected at the distance of about $4 \mathrm{~km}$ in the E from the cogeneration power plant in Vilnius (see Figure 1). Moreover, the sampling location (GPS coordinates are $54^{\circ} 40^{\prime} 03.3^{\prime \prime} \mathrm{N} ; 25^{\circ} 12^{\prime} 56.1^{\prime \prime} \mathrm{E}$ ) was located $200 \mathrm{~m}$ away from one of the main roads (Oslo str.) in Vilnius (see Figure 1), which has traffic of about 100,000 motor vehicles per day. 


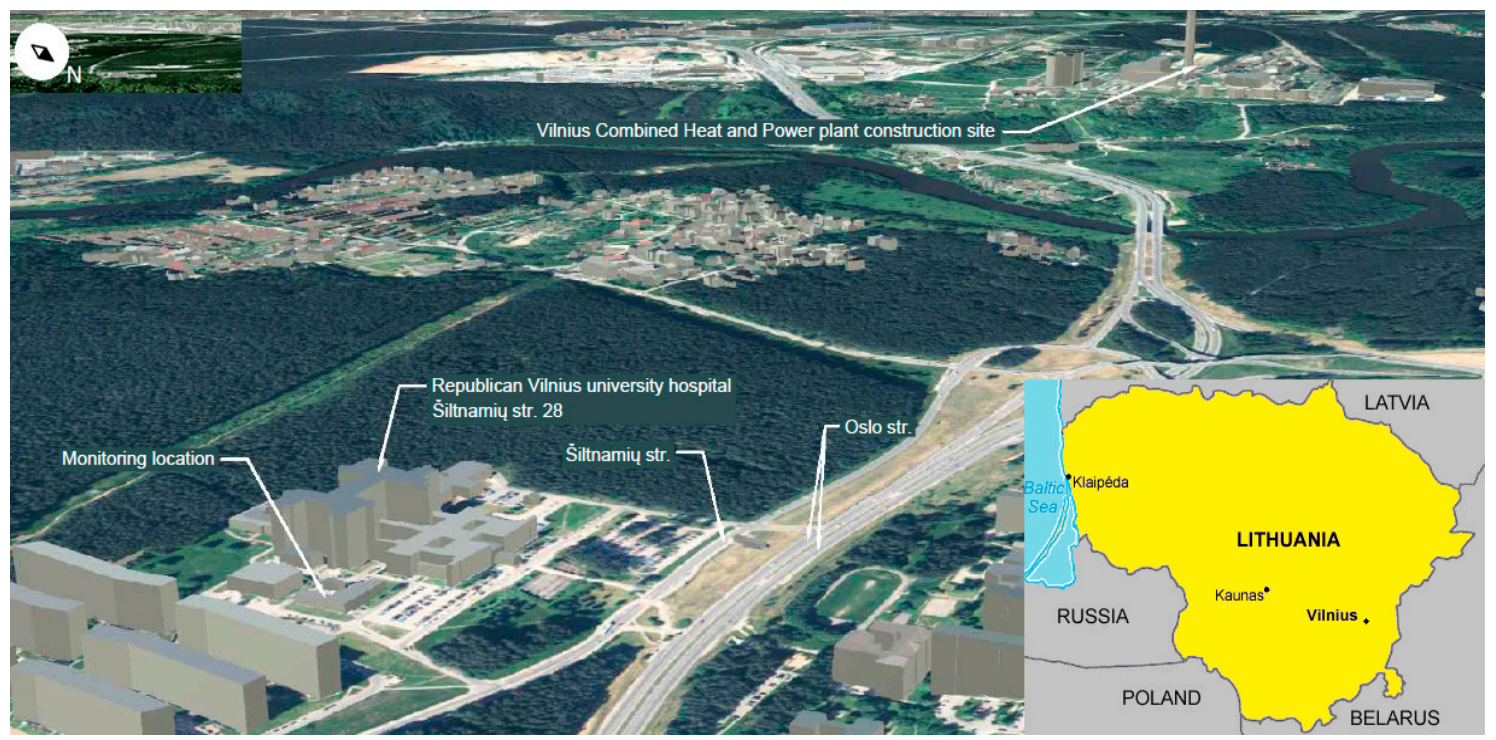

Figure 1. Map of Vilnius (source is www.google.com) Combined Heat and Power Plant construction site and PCDD/F measurement location (map of Lithuania).

Two sampling locations for monitoring of $\mathrm{PCDD} / \mathrm{F}$ concentration in air were selected in Kaunas (see Figure 2). The first site (GPS coordinates are $54^{\circ} 55^{\prime} 47.3^{\prime \prime} \mathrm{N} ; 23^{\circ} 59^{\prime} 45.2^{\prime \prime}$ E) was located approximately $500 \mathrm{~m}$ in the $\mathrm{S}$ from the cogeneration power plant. Moreover, the sampling location was located $160 \mathrm{~m}$ away from one of the most intensive highways in Lithuania Vilnius-Kaunas-Klaipeda (A1) which has traffic of about 30,000 motor vehicles per day. The second site (GPS coordinates are $54^{\circ} 56^{\prime} 27.5^{\prime \prime} \mathrm{N} ; 24^{\circ} 02^{\prime} 17.4^{\prime \prime} \mathrm{E}$ ) was located approximately $2.5 \mathrm{~km}$ in the $\mathrm{N}$ from the cogeneration power plant and at the distance of about $1.5 \mathrm{~km}$ from the highway Vilnius-Kaunas-Klaipeda.

Several $24 \mathrm{~h}$ measurements of ambient air were carried out in the period from 22 May 2017 to 9 October 2018. In addition, on-site meteorological parameters possibly affecting the dynamics of $\mathrm{PCDD} / \mathrm{F}$ concentration in air were also measured.

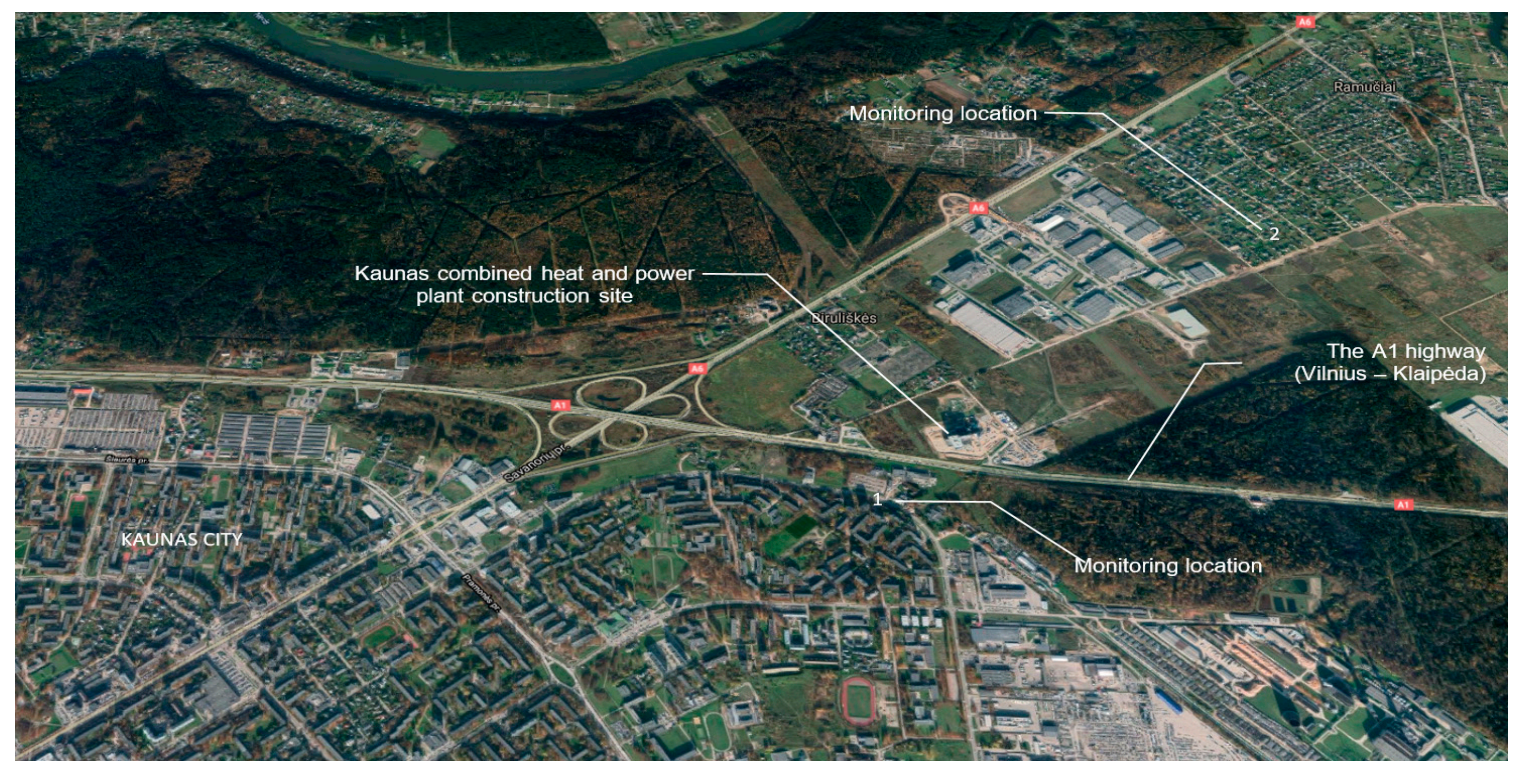

Figure 2. Map of Kaunas Combined Heat and Power Plant construction site and PCDD/F measurement location. 


\subsection{Method for Measuring PCDD/F Concentration in Air}

For PCDD/F measurements, we used DIGITEL HVS DHA-80 sequential high-volume aerosol sampler with polyurethane foam (PUF), and a filter of $150 \mathrm{~mm}$ in diameter. Samples of ambient air were collected on PUF for $24 \mathrm{~h}$ by means of a vacuum pump enhanced air flow of $30.07 \mathrm{~m}^{3} / \mathrm{h}$. The sampler's performance criteria corresponded to the European standard [37]. The Estonian Environmental Research Centre had accredited the testing laboratory (accreditation certificate no L008) and the laboratory was entitled to perform ambient air sampling for concentration measurements of PCDD/F. The laboratory was accredited against the requirements of standard EVS-EN ISO/IEC 17025:2006.

To determine PCDD/F concentration in a sample, we used analytical methods based on isotope dilution and high resolution gas chromatography/high resolution mass spectrometry (HRGC-HRMS). The toxic equivalent (TEQ) parameters were calculated from our experimentally measured values. Thus, the concentration $C$ in $\mu \mathrm{g} / \mathrm{m}^{3}$ can be expressed in terms of $C=m / V_{a}$. Here, $m$ is the mass of the air pollutant determined analytically from PUF, in $\mu \mathrm{g} /$ sample and $\mathrm{V}_{\mathrm{a}}$ is the actual volumetric flow rate of ambient air, given in $\mathrm{m}^{3}$. Limits of quantification are defined as double of detection limits. The limit of detection is defined as the rate of testing signal to noise ratio $\geq 3$. Estimation uncertainty of each 2,3,7,8-PCDD/F congener is $30 \%$ and total I-TEQ is $20 \%$. These values were ensured by analyses of certified material under conditions of internal reproducibility. This analysis of experimental data was performed by the laboratory ALS Czech Republic, s.r.o. accredited by CAI according to CSN EN ISO/IEC 17025:2005.

\subsection{Assessment of Meteorological Conditions}

Concentration of airborne PCDD/F depends on many factors, like pollution sources, strength and direction of convective air flows, air trajectories, atmospheric deposition $[33,38]$ and meteorological conditions (temperature, wind speed, wind direction, barometric pressure and humidity). For the measuring of meteorological conditions, we used the Magellan vehicle-mount mobile weather station. It features a compact sensor module with an internal fluxgate compass for self-alignment of wind direction, a wind speed sonic sensor combined with temperature, humidity and barometric pressure sensors, as well as the Weather Master 4.0 software, which automatically transfers all measured data every minute to a database. Meteorological parameters with average and $\mathrm{min} / \mathrm{max}$ values of the measurement period were measured and saved in 1-min intervals.

\section{Results and Discussion}

Based on the latest official data available from Great Britain, the national study found no evidence of an increased risk for neonatal health due to municipal-waste incinerator emissions [39]. Nevertheless, due to a high toxicity of $\mathrm{PCDD} / \mathrm{F}$, the planned incineration plants are often of great concern to the societies of the most developed countries. The industrial design of waste plants requires that the concentrations of PCDD/F entering ambient air should not exceed $0.3 \mathrm{ng} \mathrm{I}-\mathrm{TEQ} / \mathrm{m}^{3}$ [40]. This low concentration of PCDD/F can only be achieved by effective cleaning of flue gases.

Based on monitoring and modelling results, Eastern European countries make the largest contribution to the atmospheric PCDD/Fs in the Baltic Sea region. Atmospheric PCDFs dominate the current total concentrations of $\mathrm{PCDD} / \mathrm{Fs}$ in winter air. It indicates that non-industrial combustion sources are dominant, presuming that industrial production is not seasonal [41]. The impact of various industry sectors is presented in Figure 3.

Figure 4 shows atmospheric PCDD/F measured and/or calculated in different countries in Europe, USA and Japan [42]. The concentration of atmospheric dioxins in Western Europe is lower than in other parts of the world [43]. PCDD/F concentrations recorded in urban areas are close to those of reported in non-urbanized areas, suggesting that number of pollution sources is gradually decreasing [12]. Compared to other countries, the value registered in Lithuania is average $0.02 \mathrm{pg} / \mathrm{m}^{3}$ (summer season) and $0.09 \mathrm{pg} / \mathrm{m}^{3}$ (winter season) (Figure 4), which is about $7 \%$ and $30 \%$ below the limit value of 
$0.3 \mathrm{pg} / \mathrm{m}^{3}$ as recommended by WHO. The results of PCDD/F concentration studies in urbanized areas in Lithuania are similar to those in other neighbouring Baltic countries [44]. The air concentrations of PCDD/F congeners were determined in summer and winter air using high volume samplers at a rural field station (Aspvreten, Sweden) located close to the Baltic Sea coast. During winter, PCDD/F levels were on average 20 times higher than in summer, mostly due to a higher fraction of PCDFs [45]. In Portugal, the ratio of summer to winter values is approximately 1:3 for the mean, but it reaches a ratio of about 1:6 at the extreme values [46].

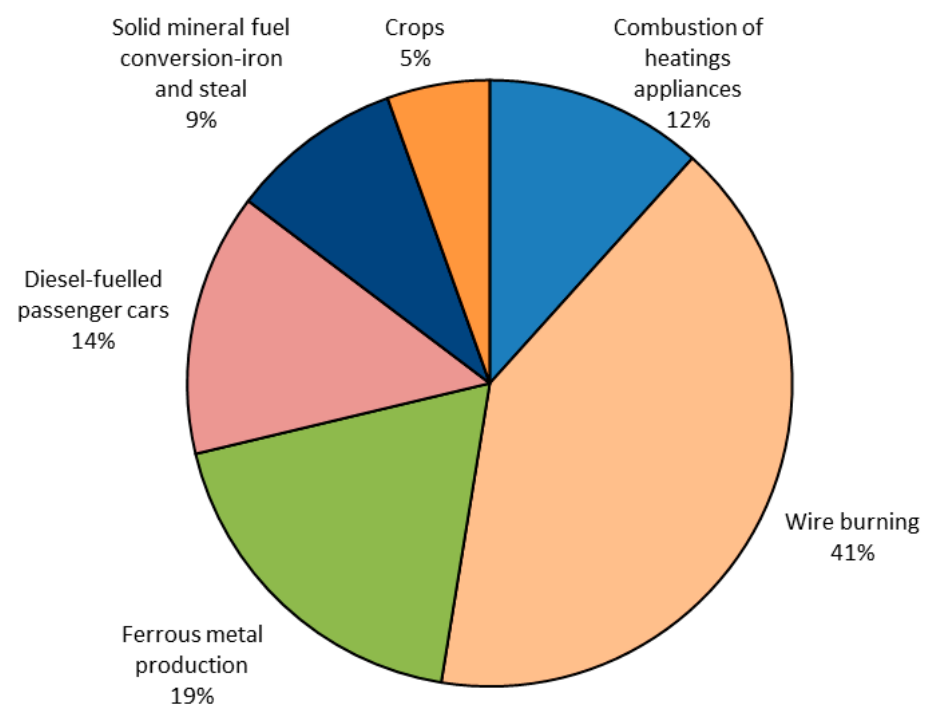

Figure 3. Summary of relative emissions from various industry sectors in 2015.

The World Health Organization (WHO) Air Quality Guidelines (2000) state that a total concentration of individual PCDD/F compounds equal to $0.3 \mathrm{pg} / \mathrm{m}^{3}$ or higher are indications of local emission sources that need to be identified and controlled. Our measured average profiles of PCDD/F congeners in ambient air in Vilnius are shown in Figure 5. Different colours in the figure represent experimental results obtained for different seasons (the ordinate axis on the left), and the hollow column represents the half-life of the specific compound (axis on the right).

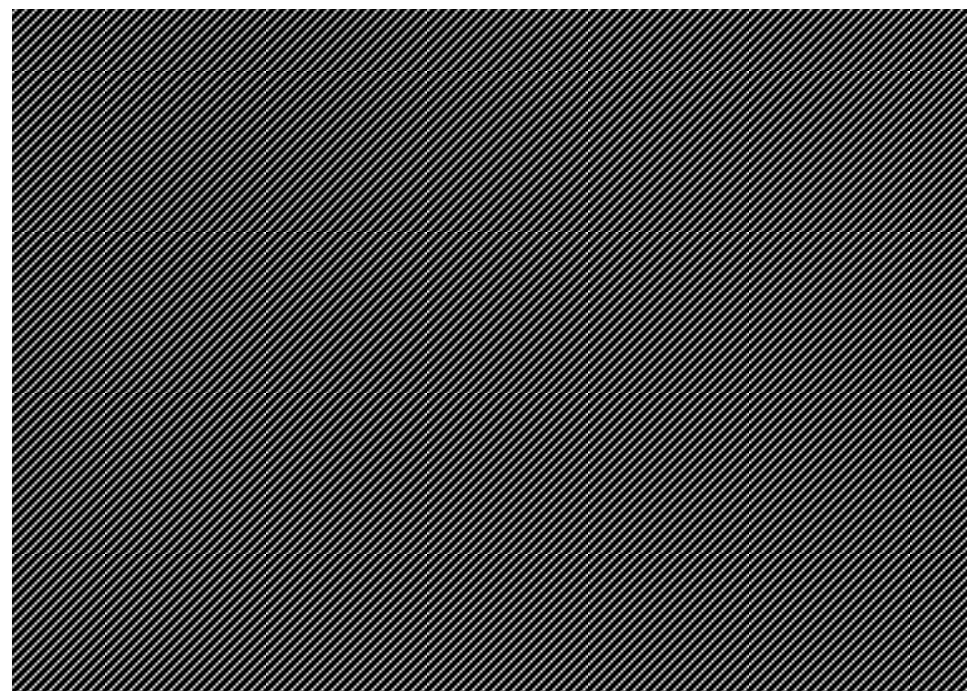

Figure 4. Atmospheric PCDD/F in urban regions of various countries. Dashed lines represent the accepted limits on presence of PCDD/F in air in various countries. 


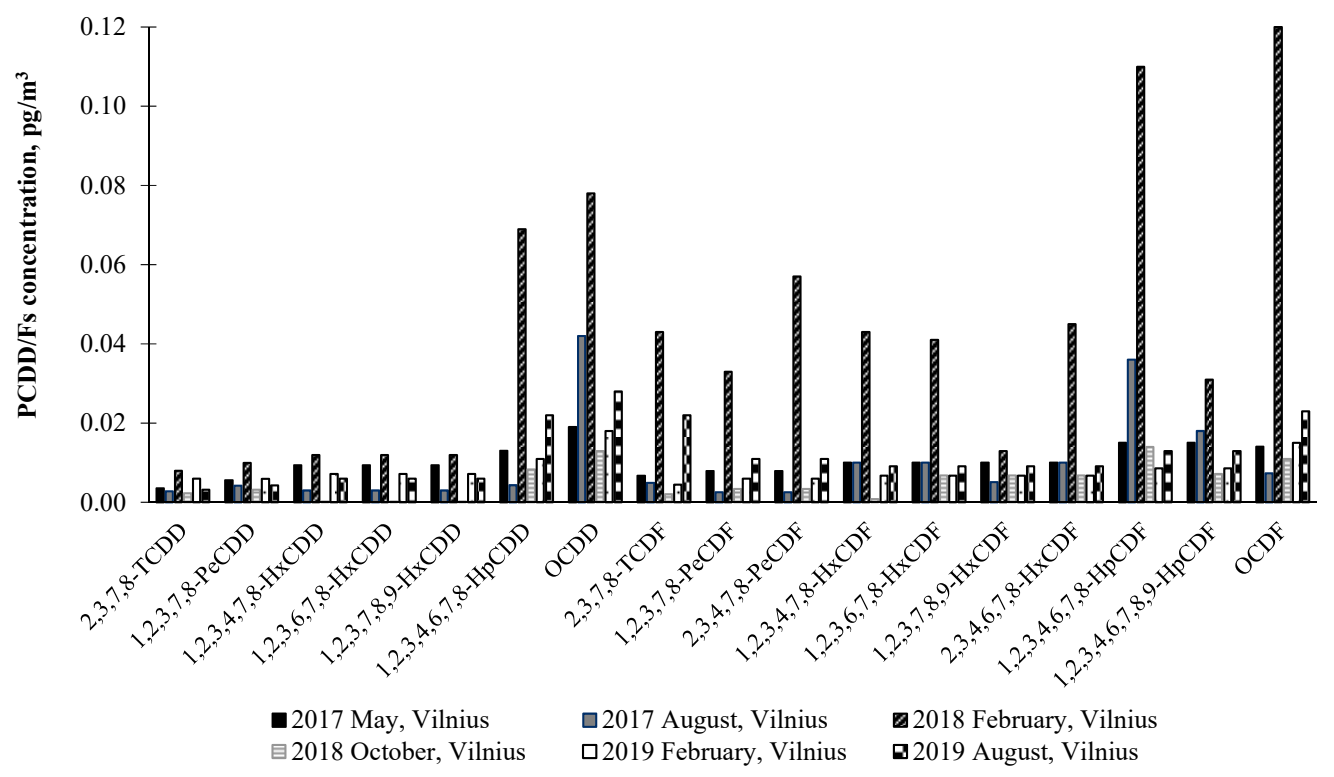

Figure 5. Relative contribution of individual compounds to total PCDD/F concentration measured in Vilnius (Vilnius-Lazdynai).

It has been experimentally determined that during the warm season, 1,2,3,4,6,7,8-HpCDF, $1,2,3,4,6,7,8,9-\mathrm{HpCDF}$ and OCDD compounds are usually found in ambient air. Their levels in the researched samples taken in Vilnius were $14 \%, 9 \%$ and 19\%, respectively (see Figure 5), and 15\%, $9 \%$ and $13 \%$, respectively, in the researched samples taken in Kaunas (see Figure 6). The key PCDD/F compounds found during the cold season were the following: 1,2,3,4,6,7,8-HpCDF, OCDD and OCDF. Their levels in the researched sample taken in Vilnius were $11 \%, 12 \%$ and $14 \%$, respectively, and $12 \%$, $24 \%$ and $8 \%$, respectively, in the researched sample taken in Kaunas. Since 2,3,4,7,8-PeCDF and $1,2,3,7,8-\mathrm{PeCDD}$ are predominantly carbon and wood combustion compounds [47], we can come to the conclusion that Vilnius and Kaunas are exposed to pollution that is mainly caused by households. Similar findings for our tests have been also presented by other authors stating that one of the main sources of pollution is uncontrolled, domestic waste burning [48-51]:

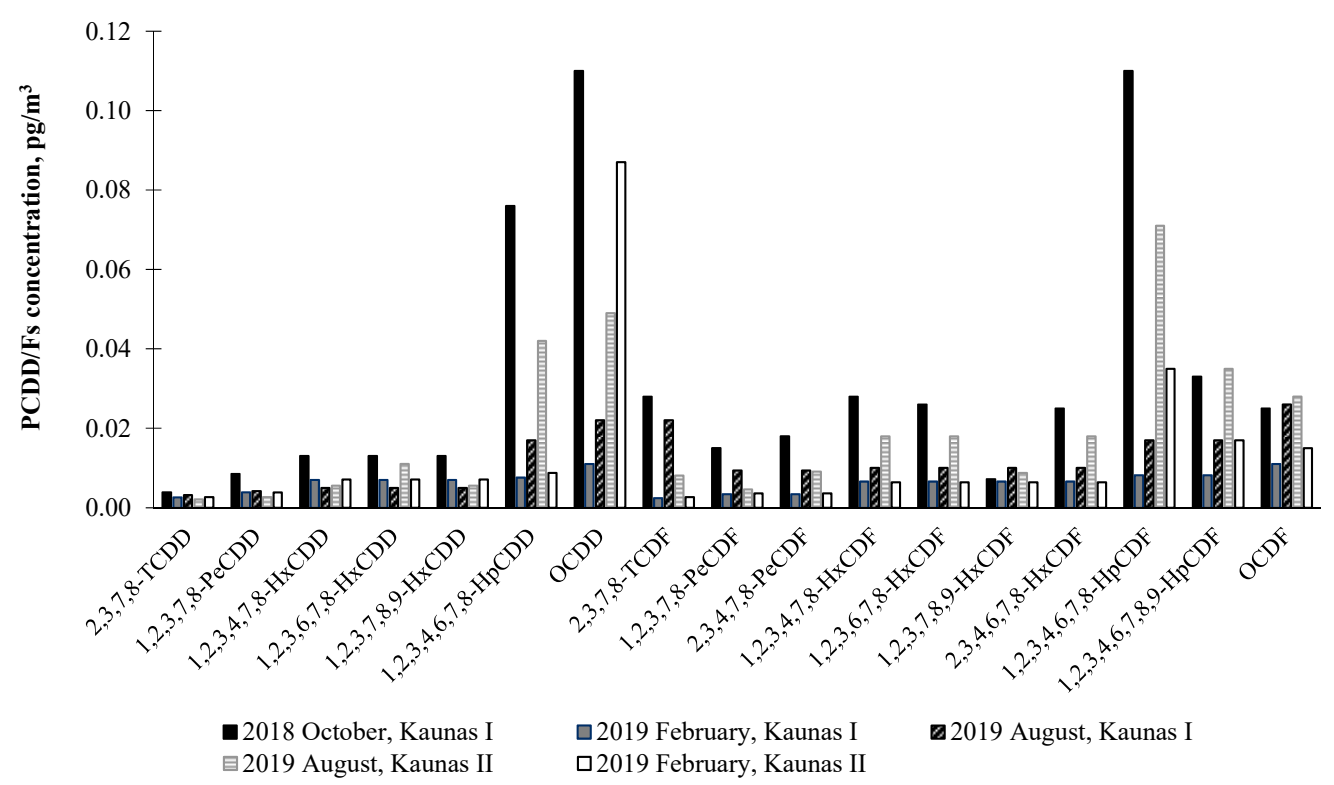

Figure 6. Relative contribution of individual compounds to total PCDD/F concentration measured in Kaunas (Kaunas I-Ramuciai, Kaunas II-Partizanu str.). 
The seasonality of PCDD/F concentration is of high interest, since it provides information on potential sources of pollution (such as home heating, certain atmospheric self-pressure processes (photolysis)) that can change seasonally. Seasonal changes in PCDD/F concentrations in ambient air are monitored and consistent with studies in other countries [52,53].

The factor that could help to explain seasonal fluctuations in PCDD/F concentrations in ambient air is the change in depth of the atmospheric mixed layer resulted from convective air motions. The depth of the atmospheric mixed layer depends on the season. Usually, it appears to be of 1000-2000 m on a sunny afternoon in summer, and decreases by several hundred meters on a cloudy winter day. The mixed layer begins to thin in the morning, but thickens rapidly at the beginning of the afternoon. In contrast, in winter, in average latitudes, there is usually more cooling at night than heat in a short day, so a stable ground layer dominates [54]. Thus, local emissions to the atmosphere are less dispersed in winter. This process is particularly effective when discharging into the ground layer, because the reduced atmosphere mixing creates favourable conditions for the accumulation of pollutants, and increases their concentrations in ambient air [55]. In addition, seasonal fluctuations in winter may be affected by the wood burning by individual households for heating. Several authors have stated that low combustion efficiency of wood burning results in low PCDD/F emissions [56-58].

An evident peak of PCDD/F congeners in Vilnius ambient air is also observed in the winter season (see Figures 5 and 7). The high concentration of these pollutants observed in February 2018 may be related to the emissions from wood and coal burning sources during the ongoing heating season. The decrease in depth of the atmospheric mixed layer and season-related weather conditions in this area might be attributable to a less effective dispersion of pollutants in ambient air.

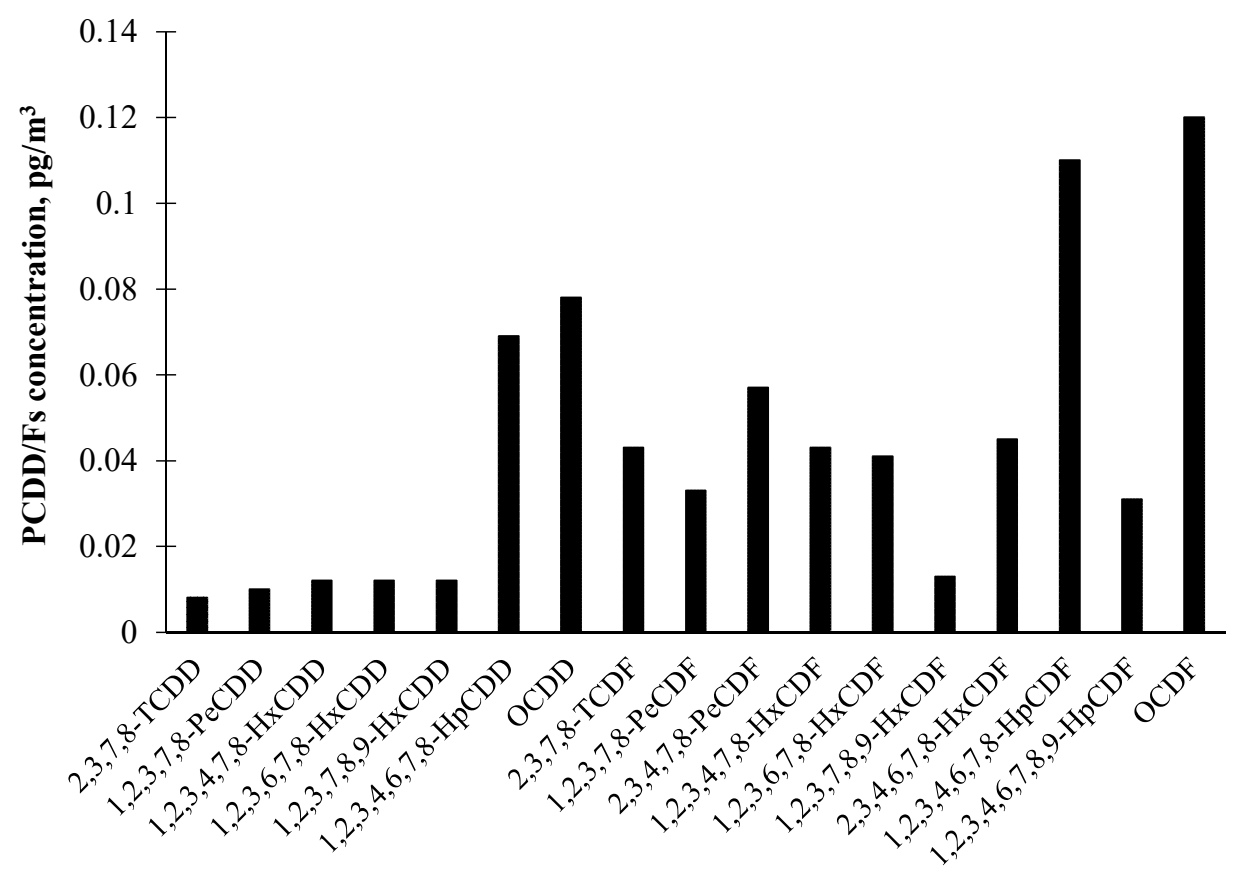

Figure 7. Maximum of PCDD/F congeners concentration in Vilnius (February 2018).

Studies of PCDD congeners revealed that the OCDD compound dominates, but the concentration ratio of 1,2,3,4,6,7,8-HpCDD over OCDD appears to be similar both in Vilnius and Kaunas. In the case of TEQ (see Figure 8), the 2,3,7,8-TCDD compound predominates over 1,2,3,7,8-PeCDD. Their average concentration in total PCDD congeners was about $43 \%$ and $32 \%$, respectively, during the warm season, and about $52 \%$ and $31 \%$, respectively, during the cold season (in Vilnius), and, accordingly, about $40 \%$ and $26 \%$, respectively, during the warm season, and about $36 \%$ and $30 \%$, respectively, during the cold season (in Kaunas). According to reference [59] and the conclusions made therein, diesel engine emissions are possibly the main sources of PCDD in Vilnius. A survey by U.S. Environmental Protection 
Agency (EPA) showed that heavy-duty diesel-engine exhaust was the sixth largest PCDD/F source in the U.S., and accounted for $4.6 \%$ of total emissions in 2000 [60,61]. A regional highway is located near the site of our laboratory for measurements, with comparatively intensive traffic (6200 cars/h), which might have affected the results of our measurements. During the measurement period, the mobile vehicle was parked in the parking lot located at S. Žukausko g. 9, Ramučiai, Kaunas district. The nearest highway which might have had some influence on the measurement results is A1 (E85) highway located approx. 1000-1500 $\mathrm{m}$ to the south-west. The additional factors that may have had some impact on the measurement results are vehicles travelling along the nearby S.Žukausko street, and emissions from plants and residential houses located in close proximity to the measurement point. Kaunas heat and power plant, as well as a railway logistics hub, are to the south-west of the measurement location. They may also have had an influence on the measurement results.

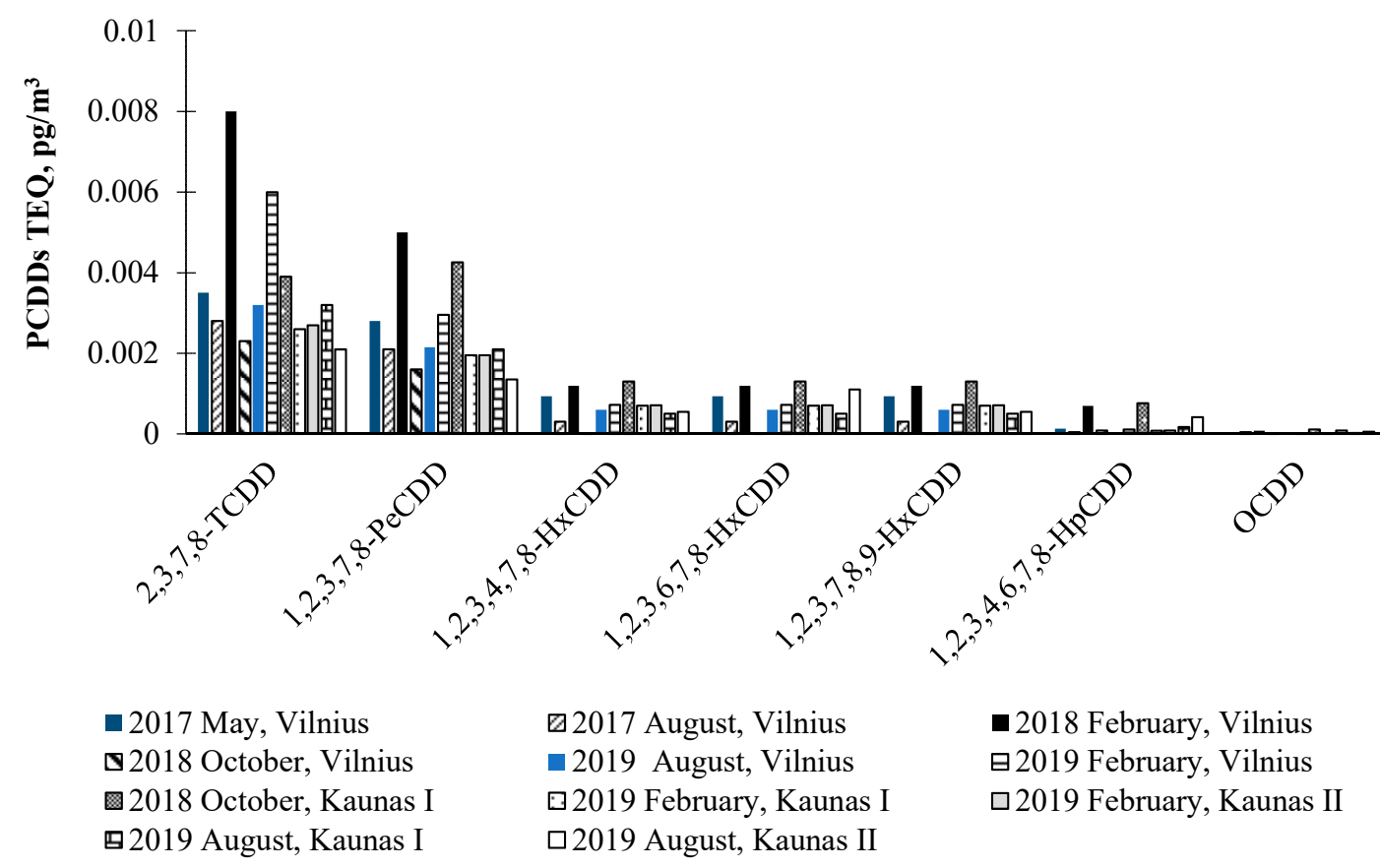

Figure 8. Polychlorinated dibenzo-p-dioxins (PCDDs) toxic equivalent (TEQ) in Vilnius and Kaunas (Vilnius-Lazdynai, Kaunas I-Ramuciai, Kaunas II-Partizanu str.).

For comparison, 2,3,4,7,8-PeCDF is predominant in PCDF congeners concentration. The obtained average concentrations of 2,3,4,7,8-PeCDF, 1,2,3,4,7,8-HxCDF, 1,2,3,6,7,8-HxCDF, 1,2,3,7,8,9-HxCDF and 2,3,4,6,7,8-HxCDF compounds in Vilnius were equal to $36 \%, 12 \%, 12 \%, 9 \%$ and $12 \%$ during the warm season, and to $47 \%, 7 \%, 11 \%, 9 \%, 11 \%$ during the cold season, respectively. Whereas, in Kaunas the obtained average concentrations for the same compounds were equal to $38 \%, 11 \%, 11 \%$, $8 \%$, and $11 \%$ during the warm season and to $36 \%, 13 \%, 12 \%, 10 \%$, and $12 \%$ during the cold season, respectively. As we see from Figure 9, the 2,3,4,7,8 PeCDF compound can be considered one of the most important deposits.

The results of air quality studies in Europe, America, Japan and Australia indicate that PCDFs TEQ contributed to PCDD/F more than 50\% [33]. Usually, TCDD/F and PeCDD/F TEQ accounts for $50 \%$, however, it should be noted that PeCDDs/Fs concentration is usually very close to or even below the detection limit, and, in most cases, researchers (including our research group) calculate TEQ by assuming that the actual amount is half the detection limit. This may lead to an overestimation of the actual contribution of these compounds to the overall PCDD/F TEQ.

The results (Figure 10) indicate that the contribution of different homologue groups to the PCDD/PCDF ratio depends on the season of the year. It was determined that the toxic equivalent of PCDF compounds in the ambient air sample taken in Vilnius may constitute more than $62 \%$ during the 
warm season and $66 \%$ during the cold season, whereas, in the air sample taken in Kaunas, it is equal to $67 \%$ during the warm season and $53 \%$ during the cold season. For PCDD compounds, this parameter reaches only $38 \%$ and $34 \%$ (in Vilnius) and 33\% and $47 \%$ (in Kaunas), respectively. The seasonal effect may be explained by influence of domestic combustion of coal and wood for household heating purposes and emissions from vehicle engines, which are expected to be higher during the cold season. TCDD, for instance, has a half-life of several years, and a very slow metabolism [62-64]. These are the most common sources of dioxin-like pollutants in the body [65-67].

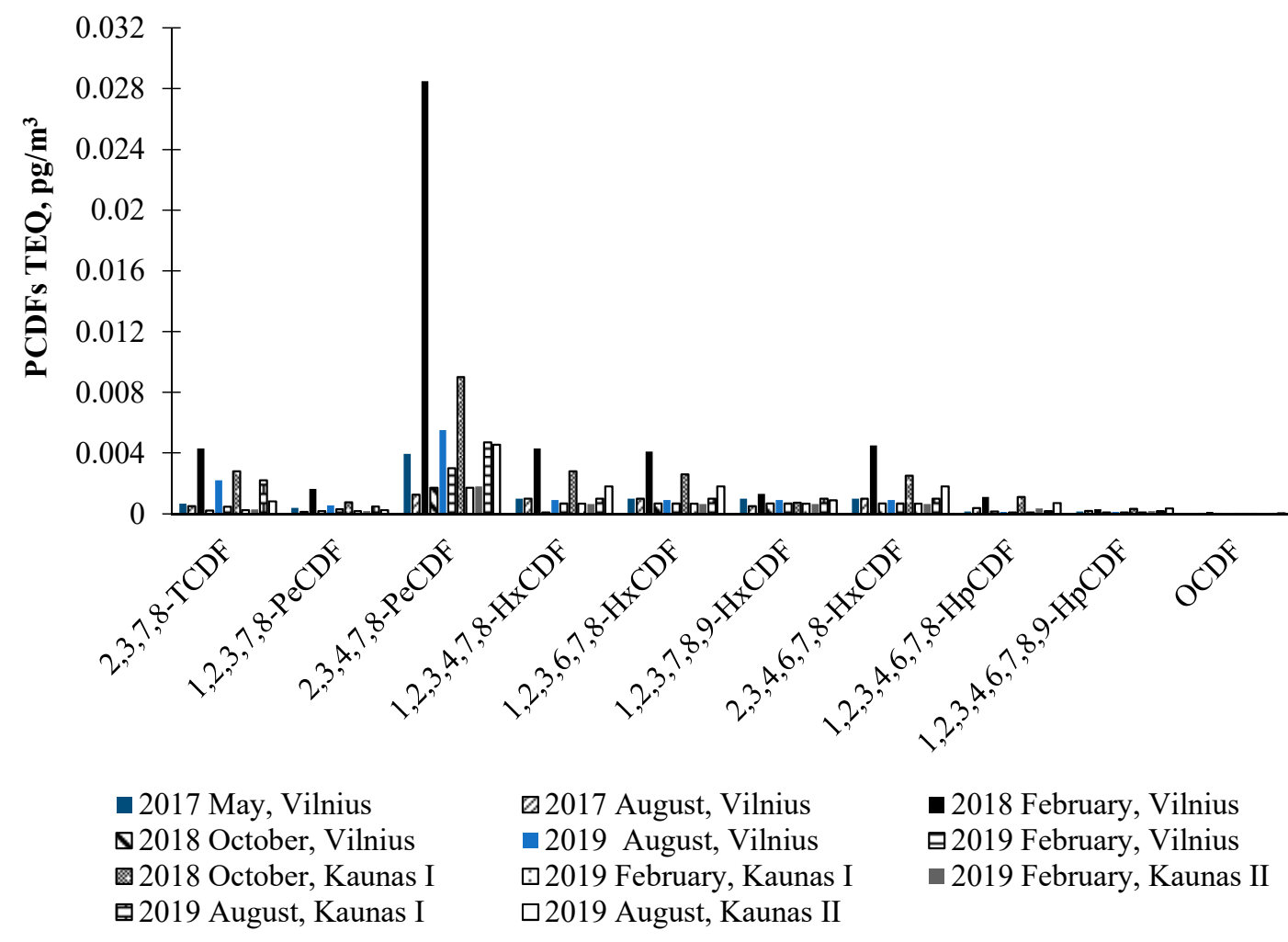

Figure 9. Polychlorinated dibenzofurans (PCDFs) TEQ in Vilnius and Kaunas (Vilnius-Lazdynai, Kaunas I-Ramuciai, Kaunas II-Partizanu str.).

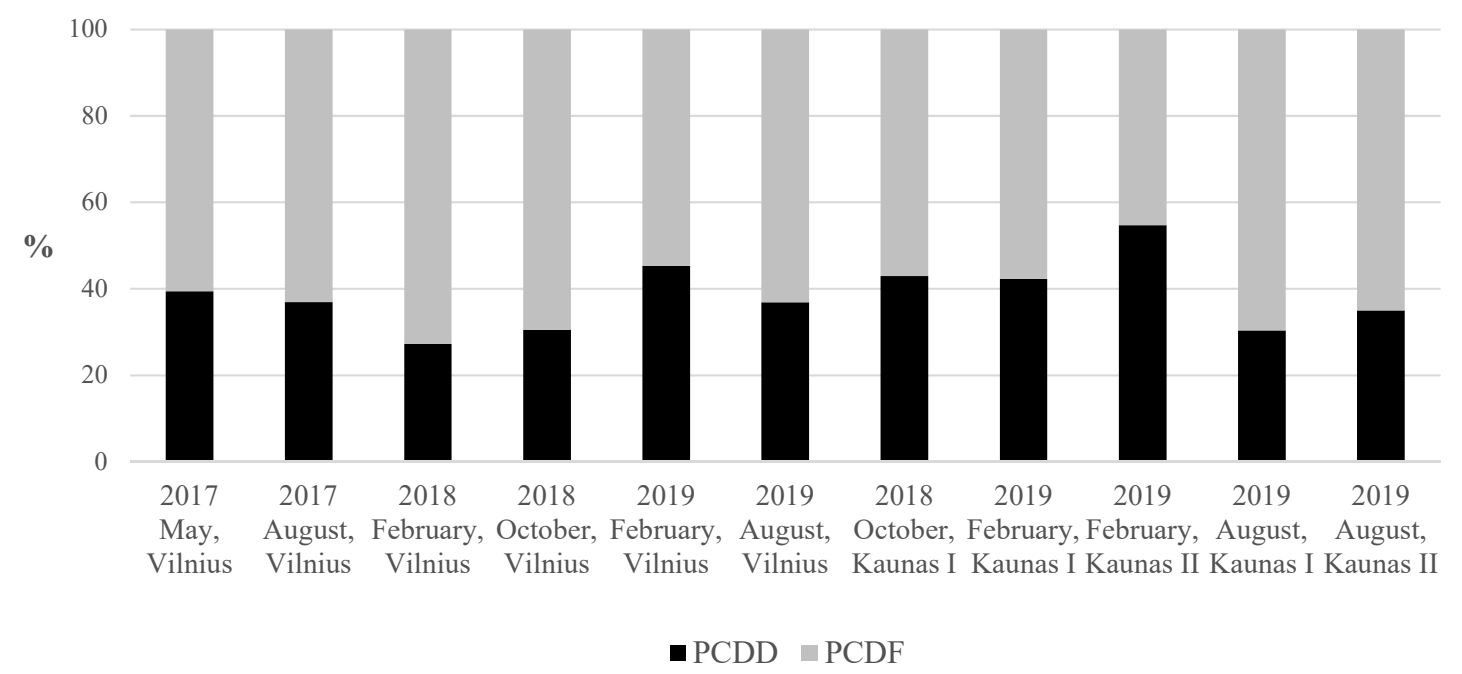

Figure 10. Percentage of total PCDD/F concentration in Vilnius and Kaunas (Vilnius-Lazdynai, Kaunas I-Ramuciai, Kaunas II-Partizanu str.). 


\section{Conclusions}

1. PCDD/PCDFs in ambient air are not national or EU limit values. In compliance with WHO Air Quality Guidelines (2000), the recommended value in ambient air is $0.3 \mathrm{pg} / \mathrm{m}^{3}$. Compared to this value, our established average value is about five times lower.

2. According to our measurement results, the concentration of $\mathrm{PCDD} / \mathrm{F}$ congeners in ambient air in Vilnius and Kaunas regions is similar to the Western countries.

3. A steady reduction in PCDD/F emissions from industrial sources has been observed year by year in all the European countries, including Lithuania. Our results confirm that the main sources of PCDD/F congeners in Lithuania could be of non-industrial origin. The factors that may have influenced the pollution are car emissions, railway and households.

4. $\mathrm{PCDD} / \mathrm{F}$ congeners are organic compounds produced by anthropogenic processes that can pose a risk to humans' health. The compound 2,3,7,8-TCDD is particularly toxic. PCDD/F emissions must be controlled and, if possible, reduced below the limit recommended by the PSO. Assuming that the generation and release of PCDD/F creates great public concerns due to their acute and chronic health effects, more detailed studies and the permanent monitoring of air quality in Vilnius and Kaunas would be appropriate.

Author Contributions: Conceptualization, R.I.-G.; investigation, V.K.; formal analysis, V.V.; data curation, R.C.; methodology, D.J. The study was completed with cooperation between all the authors. All authors have read and agree to the published version of the manuscript.

Funding: This research received no external funding.

Conflicts of Interest: The authors declare that they have no known competing financial interests or personal relationships that could have appeared to influence the work reported in this paper.

\section{References}

1. Bruckmann, P.; Hiester, E.; Klees, M.; Zetzsch, C. Trends of PCDD/F and PCB concentrations and depositions in ambient air in Northwestern Germany. Chemosphere 2013, 93, 1471-1478. [CrossRef]

2. El-Rahman, M.M.A.; Hassanin, A.S.; El-Shahat, M.F.; Nabil, Y.M. PCDD/PCDFs and PCBs in the irrigation water in Egypt: Levels, patterns, and potential sources. Environ. Monit. Assess. 2019, 191, 529. [CrossRef] [PubMed]

3. EEA (Europen Environment Agnecy). European Union Emission Inventory Report 1990-2014 under the UNECE Convention on Long-Range Transboundary Air Pollution (LRTAP) EEA Report, No 16/2016; Publications Office of the European Union: Luxembourg, 2016. Available online: https:/www.eea.europa.eu/publications/lrtap-e mission-inventory-report-2016 (accessed on 6 July 2016).

4. Quass, U.; Fermann, M.; Bröker, G. The European Dioxin Air Emission Inventory Project-Final Results. Chemosphere 2004, 54, 1319-1327. [CrossRef]

5. Lee, R.; Coleman, P.; Jones, J.; Jones, K.; Lohmann, R. Emission factors and importance of PCDD/Fs, PCBs, PCNs, PAHs and PM10 from the domestic burning of coal and wood in the UK. Environ. Sci. Technol. 2005, 39, 1436-1447. [CrossRef] [PubMed]

6. Gusev, A.; Rozovskaya, O.; Shatalov, V.; Aas, W.; Nizzetto, P. Persistent organic pollutants in the environment. EMEP 2019, 3, 2019. Available online: http://en.msceast.org/reports/3_2014.pdf (accessed on 20 June 2014).

7. Dopico, M.; Gomez, A. Review of the current state and main sources of dioxins around the world. J. Air Waste Manag. Assoc. 2015, 65, 1033-1049. [CrossRef]

8. Kulkarni, P.S.; Crespo, J.G.; Afonso, C.A.M. Dioxins sources and current remediation technologies-A review. Environ. Int. 2008, 34, 139-153. [CrossRef]

9. Mari, M.; Domingo, J.L. Toxic emissions from crematories: A review. Environ. Int. 2010, 36, 131-137. [CrossRef]

10. Defra. Environmental Key Performance Indicators, Reporting Guidelines for UK Business. Available online: https://assets.publishing.service.gov.uk/government/uploads/system/uploads/attachment_data/fil e/69281/pb11321-envkpi-guidelines-060121.pdf (accessed on 4 September 2018).

11. Saral, A.; Gunes, G.; Demir, S. Atmospheric PCDD/PCDF emission inventory for Turkey. Atmos. Pollut. Res. 2014, 5, 24-33. [CrossRef] 
12. UNEP (United Nations Environment Programme). The Emissions Gap Report, A UNEP Synthesis Report, A UNEP, Nairob; UNEP: Nairobi, Kenya, 2016; 86p.

13. Cheruiyot, N.K.; Lee, W.-I.; Yan, P.; Mwangi, J.K.; Wang, L.-C.; Gao, X.; Lin, N.-H.; Chang-Chien, G.-P. An Overview of PCDD/F Inventories and Emission Factors from Stationary and Mobile Sources: What We Know and What is Missing. Aerosol Air Qual. Res. 2016, 16, 2965-2988. [CrossRef]

14. Ikeguchi, T.; Tanaka, M. Experimental Study of Dioxin Emission from Open Burning Simulation of Selected Wastes. Organohalog. Compd. 1999, 41, 507-510.

15. Zhang, G.; Huang, X.; Liao, W.; Kang, S.; Ren, M.; Hai, J. Measurement of Dioxin Emissions from a Small-Scale Waste Incinerator in the Absence of Air Pollution Controls. Int. J. Environ. Res. Public Health 2019, $16,1267$. [CrossRef] [PubMed]

16. Lorenz, W.; Wichmann, H.; Bahadir, M. Bilanzierung der Freisetzung von polychlorierten Dibenzo-p-dioxinen und Dibenzofuranen bei Brandunfallen-Ein Diskussionsbeitrag, Gefahrstoffe. J. Reinhalt. Luft. 1996, 56, $49-53$.

17. Li, Y.M.; Jiang, G.B.; Wang, Y.W.; Wang, P.; Zhang, Q.H. Concentrations, profiles and gas-particle partitioning of PCDD/Fs, PCBs and PBDEs in the ambient air of an E-waste dismantling area, southeast China. Chin. Sci. Bull. 2008, 53, 521-528. [CrossRef]

18. Ma, Y.; Lin, X.; Chen, Z.; Li, X.; Lu, S.; Yan, J. Influence factors and mass balance of memory effect on PCDD/Femissions from the full-scale municipal solid waste incineration in China. Chemosphere 2020, 239, 124614-124741. [CrossRef]

19. Iluţiu-Varvara, D.A. An Assessment of Pollution with Polychlorinated Dibenzodioxins (PCDDs) and Polychlorinated Dibenzofuranes (PCDFs) at Steelmaking. Procedia Technol. 2016, 22, 445-451. [CrossRef]

20. Kollikkathara, N.; Feng, H.; Stern, E. A purview of waste management evolution: Special emphasis on USA. Waste Manag. 2009, 29, 974-985. [CrossRef]

21. Wang, H.C.; Chang, S.H.; Hung, P.C.; Hwang, J.F.; Chang, M.B. Synergistic effect of transition metal oxides and ozone on PCDD/F destruction. J. Hazard. Mater. 2009, 164, 1452-1459. [CrossRef]

22. Iñiguez, M.E.; Conesa, J.A.; Fullana, A. Pollutant content in marine debris and characterization by thermal decomposition. Mar. Pollut. Bull. 2017, 15, 359-365. [CrossRef]

23. Wielgosinski, G. The Reduction of Dioxin Emissions from the Processes of Heat and Power Generation. J. Air Waste Manag. Assoc. 2011, 61, 511-526. [CrossRef]

24. Han, Y.; Liu, W.; Li, H.; Lei, R.; Gao, L.; Su, G.; Liu, G. Gas-Particle Partitioning of Polychlorinated Dibenzo-p-dioxins, Dibenzofurans, and Biphenyls in Flue Gases from Municipal Solid Waste Incinerators. Aerosol Air Qual. Res. 2017, 17, 2847-2857. [CrossRef]

25. Stieglitz, L. Selected Topics on the De Novo Synthesis of PCDD/PCDF on Fly Ash. Environ. Eng. Sci. 2009, 15, 5-18. [CrossRef]

26. Li, M.; Wang, C.; Cen, K.; Ni, M.; Li, X. Emission characteristics and vapour/particulate phase distributions of PCDD/F in a hazardous waste incinerator under transient conditions. R. Soc. Open Sci. 2018, 5, 1-16. [CrossRef] [PubMed]

27. Thacker, N.; Sheikh, J.; Tamane, S.M.; Bhanarkar, A.; Majumdar, D.; Singh, K.; Chavhan, C.; Trivedi, J. Emissions of polychlorinated dibenzo-p-dioxins (PCDDs), dibenzofurans (PCDFs), and dioxin-like polychlorinated biphenyls (PCBs) to air from waste incinerators and high thermal processes in India. Environ. Monit. Assess. 2013, 185, 425-429. [CrossRef] [PubMed]

28. Bawkon, B. Incineration Technologies for Managing Solid Waste. Pollut. Eng. 1991, 23, 96-102.

29. Reis, M.F.; Miguel, J.P.; Sampaio, C.; Aguiar, P.; Melim, J.M.; Päpke, O. Determinants of dioxins and furans in blood of non-occupationally exposed populations living near Portuguese solid waste incinerators. Chemosphere 2007, 67, S224-S230. [CrossRef]

30. Vilavert, L.; Nadal, M.; Schuhmacher, M.; Domingo, J. Long-term monitoring of dioxins and furans near a municipal solid waste incinerator: Human health risks. Waste Manag. Res. 2012, 30, 908-916. [CrossRef]

31. Rovira, J.; Vilavert, L.; Nadal, M.; Schuhmacher, M.; Domingo, J.L. Temporal trends in the levels of metals, PCDD/Fs and PCBs in the vicinity of a municipal solid waste incinerator. Preliminary assessment of human health risks. Waste Manag. 2015, 43, 168-175. [CrossRef] [PubMed]

32. Ding, L.; Li, Y.M.; Wang, P.; Li, X.M.; Zhao, Z.S.; Ruan, T.; Zhang, Q.H. Spatial concentration, congener profiles and inhalation risk assessment of PCDD/Fs and PCBs in the atmosphere of Tianjin, China. Chin. Sci. Bull. 2013, 58, 971-978. [CrossRef] 
33. Gunes, G.; Saral, A. Seasonal variation of PCDD/Fs in the metropolis of Istanbul, Turkey. Environ. Sci. Pollut. Res. Int. 2014, 21, 18-29. [CrossRef] [PubMed]

34. Wcgiel, M.; Chrzaszcz, R.; Maslanka, A.; Grochowalski, A. Study on the impact of industrial flue gases on the PCDD/Fs congener profile in ambient air. Chemosphere 2014, 114, 76-83. [CrossRef] [PubMed]

35. Castro-Jimenez, J.; Mariani, G.; Vives, I.; Skejo, H.; Umlauf, G.; Zaldivar, J.M. Atmospheric concentrations, occurrence and deposition of persistent organic pollutants (POPs) in a Mediterranean coastal site (Etang de Thau, France). Environ. Pollut. 2011, 159, 1948-1956. [CrossRef] [PubMed]

36. National Strategy for Sustainable Development 2011. Available online: http://am.lrv.lt/uploads/am/documen ts/files/ES_ir_tarptautinis_bendradarbiavimas/Darnaus\%20vystymosi\%20tikslai/NDVS/NDVS.pdf (accessed on 1 September 2019).

37. DIN. Ambient Air Standard Gravimetric Measurement Method for the Determination of the pm[10] or pm[2], [5] Mass Concentration of Suspended Particulate Matter, German Institute for Standardisation, EN 12341:2014. Available online: https://infostore.saiglobal.com/en-us/Standards/DIN-EN-12341-2014-3730 15_SAIG_DIN_DIN_848913/ (accessed on 1 January 2014).

38. Yu, B.W.; Jin, G.Z.; Moon, Y.H.; Kim, M.K.; Kyoung, J.D.; Chang, Y.S. Emission of PCDD/Fs and dioxin-like PCBs from metallurgy industries in S. Korea. Chemosphere 2006, 62, 494-501. [CrossRef] [PubMed]

39. Ghosh, R.E.; Freni-Sterrantino, A.; Douglas, P.; Parkes, B.; Fecht, D.; de Hoogh, K.; Fuller, G.; Gulliver, J.; Font, A.; Smith, R.B.; et al. Fetal growth, stillbirth, infant mortality and other birth outcomes near UK municipal waste incinerators; retrospective population based cohort and case-control study. Environ. Int. 2019, 122, 151-158. [CrossRef] [PubMed]

40. WHO. Air Quality Guidelines for Europe; Regional Office for Europe, World Health Organization: Copenhagen, Denmark, 2000; 273p.

41. Wiberg, K.; Assefa, A.T.; Sundqvist, K.L.; Cousins, I.T.; Johansson, J.; Mc Lachlan, M.S.; Sobek, A.; Cornelissen, G.; Miller, A.; Hedman, J.; et al. Managing the Dioxin Problem in the Baltic Region. With Focus on Sources to Air and Fish; Swedish Environmental Protection Agency: Bromma, Sweden, 2013; 133p.

42. WHO. Updating and Revision of the Air Quality Guidelines for Europe; Report on the WHO Working Group on PCBs, PCDDs and PCDFs; WHO: Maastricht, The Netherlands, 1995; 24p.

43. UNEP (United Nations Environment Programme). Standardized Toolkit for Identification and Quantification of Dioxin and Furan Releases; UNEP Chemicals: Geneva, Switzerland, 2005; 253p.

44. Wang, B.; Fiedler, H.; Huang, J.; Deng, S.; Wang, Y.; Yu, G. A primary estimate of global PCDD/F release based on the quantity and quality of national economic and social activities. Chemosphere 2016, 151, 303-309. [CrossRef]

45. Assefa, A.; Tysklind, M.; Klanova, J.; Wiberg, K. Tracing the sources of PCDD/Fs in Baltic Sea air by using metals as source markers. Environ. Sci. Process. Impacts 2018, 20, 544-552. [CrossRef]

46. Coutinho, M.; Pereira, M.; Borrego, C. Monitoring of ambient air PCDD/F levels in Portugal. Chemosphere 2007, 67, 1715-1721. [CrossRef]

47. Lohmann, R.; Jurado, E.; Dachs, J.; Lohmann, U.; Jones, K.C. Quantifying the importance of the atmospheric sink for polychlorinated dioxins and furans relative to other global loss processes. J. Geophys. Res. 2006, 111. [CrossRef]

48. Solorzano-Ochoa, G.; de la Rosa a, D.A.; Maiz-Larralde, P.; Gullett, B.K.; Fiedler, H.; Abel, T.; Carroll, W.F., Jr. Open burning of household waste: Effect of experimental condition on combustion quality and emission of PCDD, PCDF and PCB. Chemosphere 2012, 87, 1003-1008. [CrossRef]

49. Eduliee, G.H.; Cains, P.W. The effect of changing waste management practices on PCDD/PCDF releases from household waste recycling and disposal processes. Chemosphere 1997, 34, 1615-1622. [CrossRef]

50. Lemieux, P.M.; Gullett, B.K.; Lutes, C.C.; Winterrowd, C.K.; Winters, D.L. Variables Affecting Emissions of PCDD/Fs from Uncontrolled Combustion of Household Waste in Barrels. J. Air Waste Manag. Assoc. 2012, 53, 523-531. [CrossRef]

51. Pfei, F.; Struschka, M.; Baumbach, G.; Hagenmaier, H.; Hein, K.R.G. PCDD/PCDF emissions from small firing systems in households. Chemosphere 2000, 40, 225-232. [CrossRef]

52. Gao, L.; Zhang, Q.; Liu, L.; Li, C.; Wang, Y. Spatial and seasonal distributions of polychlorinated dibenzo-p-dioxinsand dibenzofurans and polychlorinated biphenyls around a municipalsolid waste incinerator, determined using polyurethane foam passive airsamplers. Chemosphere 2014, 114, 317-326. [CrossRef] [PubMed] 
53. EPED (Environmental Protection Department). An Assessment of Dioxin Emissions in Hong Kong: Final Report; Environmental Resources Management: Kowloon, Hong Kong, 2000; 113p.

54. Stull, R. Meteorology Today for Scientists and Engineers, 2nd ed.; Brooks Cole: Pacific Grove, CA, USA, 2007; 528p.

55. Lohmann, R.; Brunciak, P.; Dachs, J.; Gigliotti, C.; Nelson, E.; Van Ry, D.; Glenn, T.; Eisenreich, S.J.; Jones, J.L.; Jones, K.C. Processes controlling diurnal variations of PCDD/Fs in the New Jersey coastal atmosphere. Atmos. Environ. 2003, 37, 959-969. [CrossRef]

56. Francosa, M.; Úbedab, X.; Pereira, P. Impact of bonfires on soil properties in an urban park in Vilnius (Lithuania). Environ. Res. 2020, 181. [CrossRef]

57. Lavric, E.; Konnov, A.; De Ruyck, J. Dioxin levels in wood combustion-A review. Biomass Bioenergy 2004, 26, 115-145. [CrossRef]

58. Vikelsoe, J.; Andersen, H.V. Dioxin in Danish air. Organohalog. Compd. 2004, 66, 2203-2208.

59. Shen, H.; Guan, R.; Ding, G.; Chen, Q.; Lou, X.; Chen, Z.; Zhang, L.; Xing, M.; Han, J.; Wu, Y. Polychlorinated dibenzo-p-dioxins/furans (PCDD/Fs) and polychlorinated biphenyls (PCBs) in Zhejiang foods (2006-2015): Market basket and polluted areas. Sci. Total Environ. 2017, 574, 120-127. [CrossRef]

60. United States Environmental Protection Agency. An Inventory of Sources and Environmental Releases of Dioxin-Like Compounds in the United States for the Years 1987, 1995, and 2000, November 2006 External Review Draft. EPA/600/P-03/002F; United States Environmental Protection Agency: Washington, DC, USA, 2006; 285p.

61. Li, H.; Zhou, L.; Ren, M.; Sheng, G.; Fu, J.; Peng, P. Levels, profiles and gas-particle distribution of atmospheric PCDD/Fs in vehicle parking lots of a South China metropolitan area. Chemosphere 2014, 94, 128-134. [CrossRef]

62. Aylward, L.L.; Brunet, R.C.; Carrier, G.; Hays, S.M.; Cushing, C.A.; Needham, L.L.; Patterson, D.G.; Gerthoux, P.M.; Brambilla, P.; Mocarelli, P. Concentration-dependent TCDD elimination kinetics in humans: Toxicokinetic modeling for moderately to highly exposed adults from Seveso, Italy, and Vienna, Austria, and impact on dose estimates for the NIOSH cohort. J. Expo. Anal. Environ. Epidemiol. 2005, 15, 51-65. [CrossRef]

63. Geusau, A.; Tschachler, E.; Meixner, M.; Papke, O.; Stingl, G.; McLachlan, M. Cutaneous elimination of 2,3,7,8-tetrachlorodibenzo-p-dioxin. Br. J. Dermatol. 2001, 145, 938-943. [CrossRef]

64. Sorg, O.; Zennegg, M.; Schmid, P.; Fedosyuk, R.; Valikhnovskyi, R.; Gaide, O.; Kniazevych, V.; Saurat, J.H. 2,3,7,8-tetrachlorodibenzo-p-dioxin (TCDD) poisoning in Victor Yushchenko: Identification and measurement of TCDD metabolites. Lancet 2009, 374, 1179-1185. [CrossRef]

65. Hsu, J.-F.; Guo, Y.L.; Liu, C.-H.; Hu, S.-C.; Wang, J.-N.; Liao, P.-C. A comparison of PCDD/PCDFs exposure in infants via formula milk or breast milk feeding. Chemosphere 2007, 66, 311-319. [CrossRef] [PubMed]

66. Sorg, O. AhR signalling and dioxin toxicity. Toxicol. Lett. 2014, 230, 225-233. [CrossRef] [PubMed]

67. Martínez, K.; Ramadan, A.; Gevao, B. Atmospheric concentration of polychlorinated dibenzo-p-dioxins, polychlorinated dibenzofurans (PCDD/Fs) and dioxin-like polychlorinated biphenyls (dl-PCBs) at Umm-Al-Aish oil field-Kuwait. Chemosphere 2017, 168, 147-154. [CrossRef] [PubMed]

(C) 2020 by the authors. Licensee MDPI, Basel, Switzerland. This article is an open access article distributed under the terms and conditions of the Creative Commons Attribution (CC BY) license (http://creativecommons.org/licenses/by/4.0/). 